\title{
Impact of Television Advertisements on Children's Mental and Physical Development in Bangladesh
}

\author{
Mazidul Islam ${ }^{*}$, Md. Usman Goni ${ }^{2}$ \\ ${ }^{1 *}$ Lecturer, Mass Communication and Journalism Discipline, \\ Khulna University, Khulna, Bangladesh \\ ${ }^{2}$ Postgraduate Student, Mass Communication and Journalism Discipline \\ Khulna University, Khulna, Bangladesh
}

*(mazid.mithu@ku.ac.bd )

This journal is licensed under a Creative Commons Attribution-NonCommercial 4.0 International License (CC-BY-NC).

Articles can be read and shared for noncommercial purposes under the following conditions:

- BY: Attribution must be given to the original source (Attribution)

- NC: Works may not be used for commercial purposes (Noncommercial)

This license lets others remix, tweak, and build upon your work non-commercially, and although their new works must also acknowledge you and be non-commercial, they don't have to license their derivative works on the same terms. License Deed Link: http://creativecommons.org/licenses/by-nc/4.0/

Legal Code Link: http://creativecommons.org/licenses/by-nc/4.0/legalcode

$A B C$ Research Alert uses the CC BY-NC to protect the author's work from misuse.

\section{Abstract}

Nowadays television advertisement is becoming a day to day activity of passing the time of the people and it is largely used to influence viewers' purchase decisions. But there are a lot of negative and positive impacts of TV ads on children. This study aims to know both impacts of ads on the children of Bagerhat Sadar Upazila in Bangladesh by collecting the data from children and their parents. This research was quantitative and exploratory in nature. The survey method was used for conducting the study. From the total number of the residents of Bagerhat Sadar Upazila, 125 families were collected by following proportionate systematic random sampling. The study shows that most of the respondents watch television on holiday and spend two to four hours to watch the television. The study presents that the maximum number of respondents is attracted to toys advertisements on television. The study also reveals that the majority of the respondent's behavior changes after watching the advertisements. The study also discloses that highest number of respondents wishes to buy the products after watching the advertisements and they inform them of their parents. The study also shows that most of the respondents want to act what they watch on television.

\section{Keywords}

Children, Impact, Television Advertisement

\section{INTRODUCTION}

Maximum influence of mass media is driven from advertising and programming. Basically, ads are shown for displaying commercial products and maximize the number of customers (https://press.rebus.communit). Oxford Dictionary defines advertisement as, "A notice, picture or film telling people about a product, job or service." On the other hand, "Advertising is a marketing communication that employs an openly sponsored, non-personal message to promote or sell a product, service or idea" (William J. Santon, 1984). TV advertisements are always shown to display the products by drawing the 
attention of the viewers. But these ads have a lot of impact on children. These ads on TV increase their brand awareness and they often ask for products that they watch on TV. Sometimes, ads change their behavior and make them stubborn. Young children have the ability to differentiate between a TV ads and an entertainment program. But they do not have the ability to understand the intent of advertising probably till 7 to 12 years old. In this study, we have categorized the samples who were 7 to 12 years old children and their parents. As the children do not have the ability to understand the content of ads, they are used to nag for buying the products shown in ads. As a result, it creates problem for the parents. Besides, the children are habituated with watching TV ads that they cannot do daily activities like eating, reading, sleeping without watching them. Besides, the behavior and psyche of the children change after being used to watching the ads. Moreover, there are some cases where TV ads are beneficial. These can help them in building good habits and civic sense.

\subsection{Statement of the Problem}

Nowadays children spend a large portion of their time by watching TV and different TV channels show ads in between their programs. These ads motivate the children to buy their products by displaying attractive things. The children's psychology and demand change after watching and scrutinizing the ads. They trouble their parents by demanding these products and parents do not always agree. This creates a problem among parents and children. Besides, by watching ads children spend their leisure and do not pay attention to their academic activities. In fact, sometimes they are more interested to watch ads rather than other interesting learning programs. So, in this research I have wanted to point out these issues by collecting and examining the children's and parents' view in TV ads through dependent and independent variables.

\subsection{Objectives of the Study}

To explore the variability in the impact of TV ads among the children from 7 to 12 years in Bagerhat Sadar and to identify the factors of such variables. Specific Objectives are:

1. To find out which factors have more impact on children behavior

2. To explore how these ads change the behavior, attitude and lifestyle of the children

\section{LITERATURE REVIEW}

The literature reviews of the factors in which we study about the previous research made on that factor that how these factor changes the children behavior in definite way and what the consequences about the factors.

Mr. Abdul Hameed (2014), asserted a study on "Impact of TV Advertisement on Children Buying Behavior" In their research they investigate the impact of television advertisements on children buying behavior. They visited different schools in Punjab, Pakistan and checked the response of children. A 5point liker scale questionnaire was designed. Different cities of Punjab were selected on random sampling basis. A total 250 questionnaires were circulated, and the response rate was $100 \%$.

Gulraiz Ghaffar, Usma Noreen (2016), employed a study on "Impact of Television Advertisement on Children's Behavior" In this research paper we examine how TV advertisements are associated with children's behavior in today's children from District Gujrat, Pakistan. They investigate the impact of different types of TV advertisements that was Food Advertisement, Violent advertisement, Music advertisement, Exposure in Advertisement and Repetition of Advertisement on children's buying behavior. This research goals to answer the questions that whether the residential background of children i.e. rural, urban and semi urban has a changeable impact on the behavior due to the television advertisements. They also compare the impact of television advertisements among having different educational background and among those having different income level households. For this purpose, they visited different areas in Gujrat, Pakistan and checked the response of children's parent.

Sunita Kumar(2013), carried out a study on "The Impact of Television Advertisements on Children in the Process of family purchase decision" This study has been done to study the impact (knowledge of brands and products and food habits) of television advertisement on children and to what extent 
television advertisement impacts children in influencing family purchase decisions. To achieve the objective survey using 5point Likert type scale is used. The reliability test using SPSS is performed. The table matrices and one-way ANOVA are used as a statistical tool. It is found that TV advertisements improve brand consciousness, knowledge about various products in any category. Because of this, children influence the family purchase decision and parent often value their opinion.

Galdolage B.S., Wijesundara C.B. (2016), discovered on "Impact of TV Advertising on Children's Behavior" The study was conducted by using both primary and secondary data. The primary datawere collected through the survey conducted in three (3) selected areas (Colombo,Gampaha and Kalutara) of the Western province and, prescheduled questionnaires were distributed among a sample of 200 parents and children, which is enough for generalization of results. In selecting them, nonrandom convenience sampling tool was employed in accordance with the judgment of the researchers. Secondary data were collected by relevant journals, reports, articles, published data of relevant authorities and the Internet. Descriptive statistical techniques were utilized to analyze the data with the help of the SPSS package. The major statistical techniques which were used in this study are the percentage analysis, correlation and regression analysis.

Siana Petrova (2016), researched on "Investigating the effects of television advertising on children aged 8-11 in transitional Bulgaria" Empirical evidence whether these assumptions would also be valid for an 'Eastern', economically developing setting, is however missing. To challenge this, the present study employs a survey research among 273 Bulgarian children (aged 8-11 years). An investigation whether the amount of television advertising they get exposed to makes them more materialistic and consumer oriented, and less happy, is conducted. Furthermore, a closer look in the advertising literacy capabilities of children is taken as a response to an expected difference in the levels of advertising literacy among the survey participants. More specifically, since part of the sample consists of children who attend a private acting school and are actively involved in the advertising industry, they are expected to be more advertising literate than the other study participants, who are enrolled in general state schools. Moreover, this difference in school background and the associated variance in advertising literacy abilities are thought to determine the magnitude of the television advertising effects on children, in a way that those with state school background would be affected stronger. A combination of regression and independent $\mathrm{t}$-test analyses confirm the expected associations between exposure to television advertising and materialism and consumer involvement, as well as confirm the assumption that the children-actors would appear better advertising literate.

\subsection{Theoretical Framework}

Cultivation theory or Cultivation hypothesis or Cultivation analysis was developed by Professor George Gerbner. Gerbner developed this theory on the basis of his mid-60's research project on 'cultural indicators'. The research was conducted to find out how watching television affects viewers' perception. In 1976, Gerbner along with Gross expanded the theory and included media effects while focusing on television. They published their research in Journal of Communication under the title 'living with television: the violence profile' (Gerbner and Gross, 1976).

The theory tried to understand how media affects people's perception. According to the research, media cultivates and shapes viewers perception of social reality. The focus of cultivation theory is the spontaneous influence on the viewers.

Viewers are said to be cultivating behaviors by watching virtual and fictional things from television.

\subsection{Concepts of cultivation theory}

The more someone watches television, the more he/she is influenced by media. These kinds of people are most vulnerable to media messages and agendas. They believe whatever media claims to be true and accurate. Media does not let there be much difference between real and virtual. And, even fictions are taken to be real.

People who watch television for less than 4 hours a day are light viewers. And, people who watch television for 4 or more hours a day are heavy viewers. According to this theory, television has long-term effects. So 
it is regarded to be the most used tool in this theory. It creates patterns and models on the fake realities of the world. Media is likely to expose people to violence and negativity. As a result, people become afraid to face the world. They start developing a mental condition called Mean World Syndrome and perceive the world to be mean to them (Evra, Judith van 1990).

\subsection{Relationship between cultivation theory and this study}

There is a close relationship between cultivation theory and impact of television ads on children. Those are 1. By showing specific topics again and again media influence the audience. Children begins to believe what its see, television ads show some vague contents regularly so it creates an impact on children.

2. Cultivation theory tells that the theory follow a long term process, in the same manner television ads effect on children follow a long term process.

3. Different ads about child products show the contents of heroic nature, intelligence, analytical ability of children again and again. By this process children affects and believes the advertisements. Cultivation is also the same thing.

4. According to cultivation theory, audience is considered as children because it cultivates the certain issue among audience.

From above discussion it is cleared that there is a strong relationship between cultivation theory and ads effect on children.

\section{RESEARCH METHODOLOGY}

\subsection{Methods of the study}

This research was quantitative and exploratory in nature because we tried to find out the impact of TV ads on children from the residents of 10 unions Bagerhat Sadar Upazila. The study was carried out following survey method because it is widely used in quantitative research and helps to gather more accurate information from a large population within short period of time. Regarding in the view the nature and requirement of the present study, survey method was adopted to explore and examine the impact of TV ads on children.

\subsection{Study Area}

All the unions under Bagerhat Sadar was the study area for this study. Bagerhat Sadar is the Upazila of Bagerhat district. It was established in 1958. It has 45, 527 households and a total area of $272.73 \mathrm{k} . \mathrm{m}$ (http://en.banglapedia.org). It consists of 10 unions: Karapara, Bemorta, Gotapara, Bisnupur, Baruipara, Jatrapur, Shatgambuj, Khanpur, Rakhalgachi, Dema.

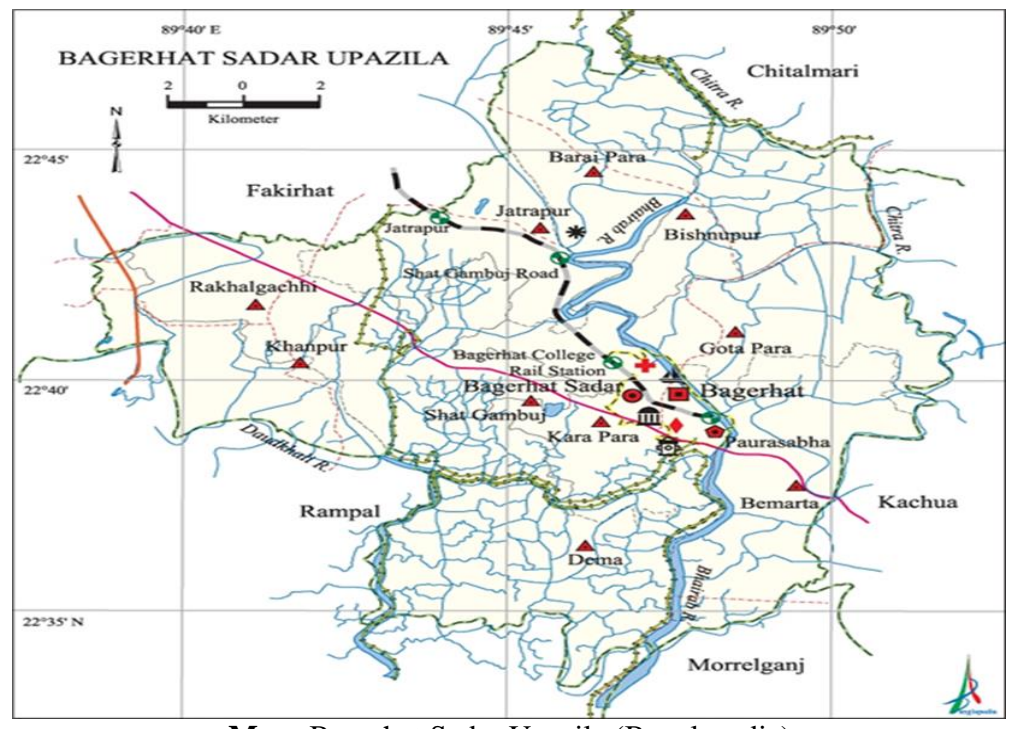

Map: Bagerhat Sadar Upazila (Banglapedia) 


\subsection{Population of the study}

There were about 4500 families in Bagerhat Sadar Upazila. Regarding in the view the requirement of the present study, the population was taken from 10 unions of Bagerhat Sadar Upazila. The population of the study involved the opinions of both the parents and the children.

\subsection{Sampling}

From the total number of the residents of Bagerhat Sadar Upazila, 125 families were collected by following proportionate systematic random sampling. This sample size was calculated considering 95 percent confidence level with a confidence interval of 20 . However, the participants were picked proportionately from each union with a unique sample size calculation.

\subsection{Data collection tools}

Questionnaire was used for collecting data. For this purpose, a semi-structured questionnaire was developed and finalized for data collection.

\subsubsection{Questionnaire}

A semi-structured questionnaire containing both open-ended and close ended questions relating to the impact of TV ads on children was used for data collection. Because, it was helpful to collect information from a large sample size and respondent had much time to provide their opinion without any hesitation.

\subsection{Study Period}

This study was carried out following survey method covering a representative sample from the list. The information from the samples was collected by a structured questionnaire developed after reviewing relevant literatures and the data were collected from the respondents of Bagerhat Sadar Upazila in a month period, started from February 2019 to October 2019.

\subsection{Data Processing}

After ending of the field work, the Questionnaire was checked and edited to minimize the incompleteness of the data extracted from the participants. Then, the data were classified into dependent and independent variables.

\section{Independent Variable}

\subsubsection{Information about Parents}

This included name, age, sex, permanent residence, academic background, monthly income etc.

\subsubsection{Information about children}

Description of the children's name, age, academic status, etc. were included here.

\section{Dependent Variable}

Dependent variable was the impact of TV ads on the participants.

\subsection{Data Analysis and Interpretation}

Data were entered into SPSS $®$ for statistical analysis. This study was quantitative in nature. Through descriptive statistics, the personal descriptions as well as their family description were described. To 
measure the association between dependent and independent variables, Pearson's Chi-square $(\chi 2)$ as well as Pearson's 'r' is used. Fisher's Exact Test was executed to justify the relations.

\subsection{Ethical Consideration}

Prior to start actual fieldwork, the researcher disclosed the nature and purpose of this research work and took verbal consent from the participants, willing to take part in this work voluntarily. The participants were free to accept or reject to take part in the study and go back from the study at any moment of the survey.

\section{RESULTS}

\subsection{Gender}

In this study the total numbers of the population are 2500 and sample size is only 125 . Among of them (43.2\%) respondents are male whereas $(56.8 \%)$ respondents are female. Therefore, the number of female respondents is more than the numbers of male respondents.

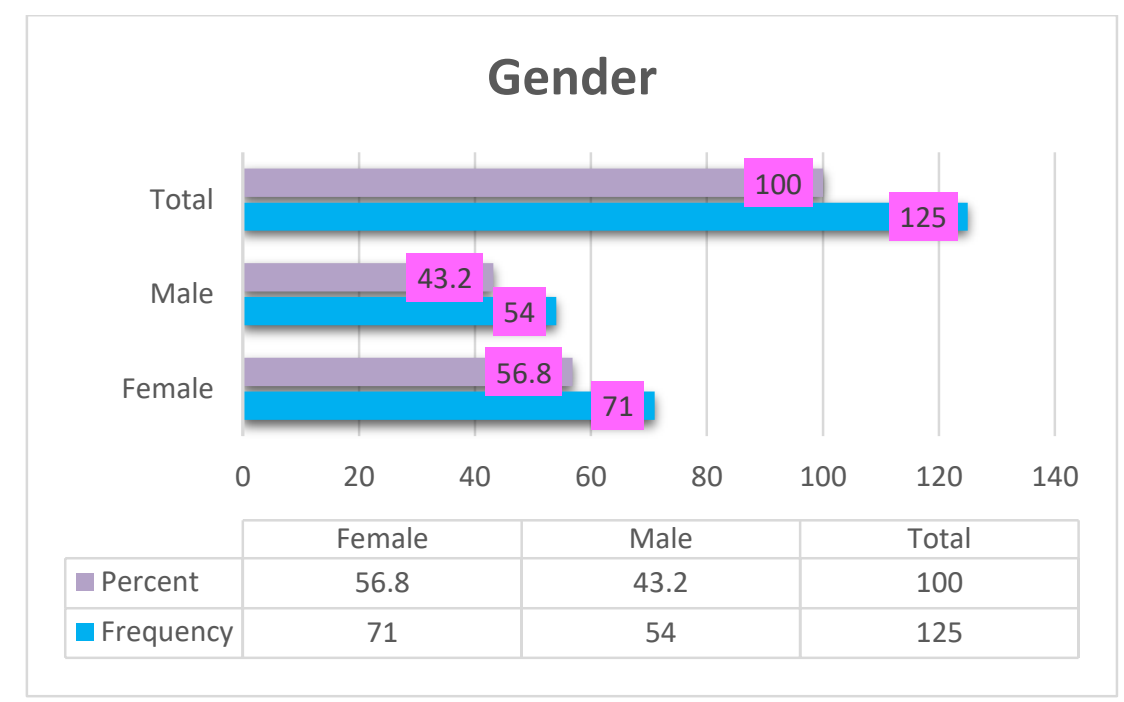

Figure-1: Gender

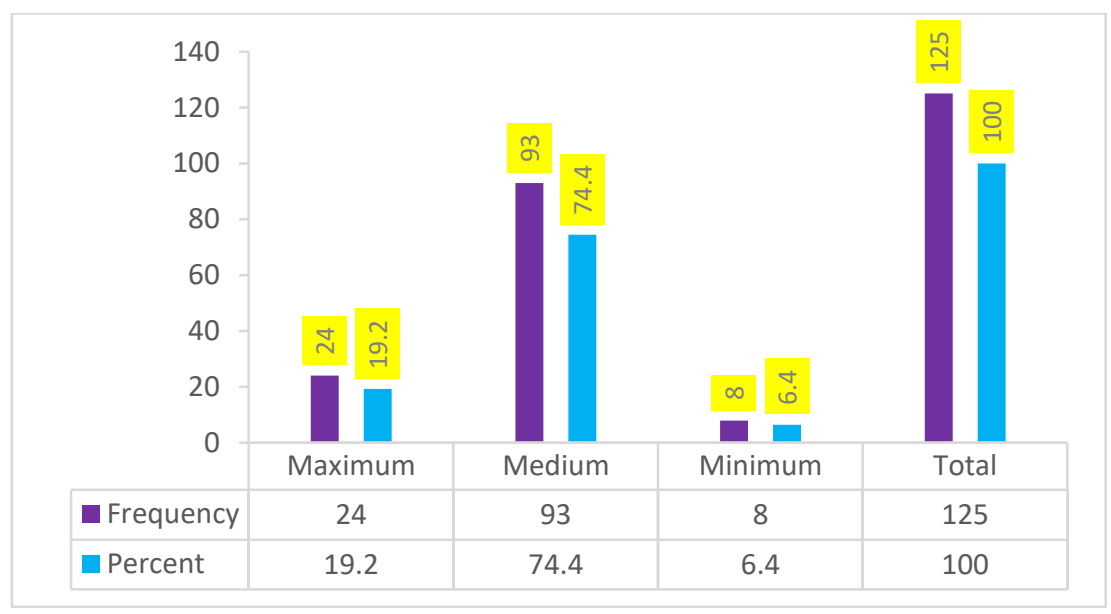

Figure-2: Children's interest in watching television.

Figure-2 shows that most of the respondents $93(74.4 \%)$ watch television as medium while second largest of the respondents $24(19.2 \%)$ watch the television as maximum and lower respondents $8(6.4 \%)$ watch the television as minimum. 


\subsection{Children's interest in watching ads and the amount of time}

\begin{tabular}{|l|c|c|}
\hline & Frequency & Percent \\
\hline MORE THAN SIX & 3 & 2.4 \\
\hline FOUR TO SIX & 26 & 20.8 \\
\hline TWO TO FOUR & 82 & 65.6 \\
\hline LESS THAN TWO & 14 & 11.2 \\
\hline TOTAL & 125 & 100 \\
\hline
\end{tabular}

Table-1: Children's interest in watching ads and the amount of time.

Table-1 represents most of the respondents $82(65.6 \%)$ who spend two to four hours to watch television while second largest respondents 26 (20.8\%) spend four to six hours to watch television. 14 (11.2\%) respondents spend less than two hours to watch television and lower $3(2.4 \%)$ respondents spend more than six hours to watch television as per day.

\begin{tabular}{|l|c|c|}
\hline & Frequency & Percent \\
\hline MORNING & 2 & 1.6 \\
\hline AFTER COMING TO SCHOOL & 21 & 16.8 \\
\hline AFTER NOON & 33 & 26.4 \\
\hline EVENING & 33 & 26.4 \\
\hline HOLIDAY & 36 & 28.8 \\
\hline TOTAL & 125 & 100 \\
\hline
\end{tabular}

Table-2: Children's maximum time of watching television.

Table-2 shows highest number of the respondents 36 (28.8\%) spend long time to watch television in the holiday while second largest $34(26.4 \%)$ respondents spend long time to watch television in the afternoon as well as the same respondents spend long time to watch television in the evening. 21 $(16.8 \%)$ respondents spend long time to watch television in the after coming to school and lower part of the respondents $2(1.6 \%)$ spend long time to watch television in the morning.

\subsection{Usage of dish-line}

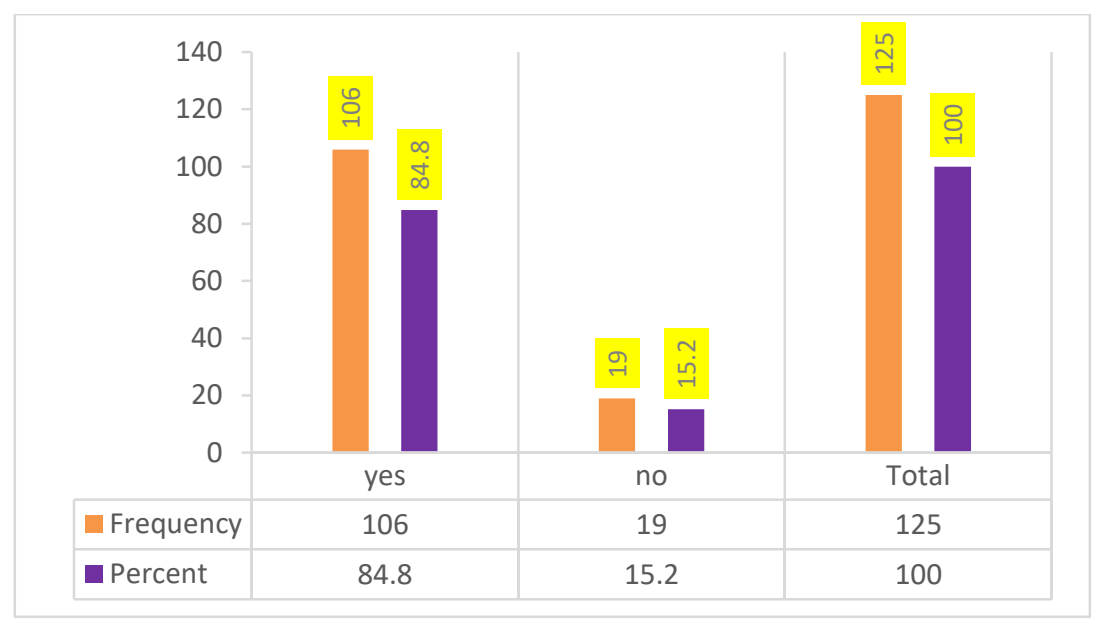

Figure-3: Usage of dish-line

Figure-3 highlights that most of the respondents who are 106 in number $(84.8 \%)$ take dish-line in their house while lower part of the respondents who are 19 in number $(15.2 \%)$ do not take dish-line in their house. 


\subsection{Children's reaction after watching advertisements}

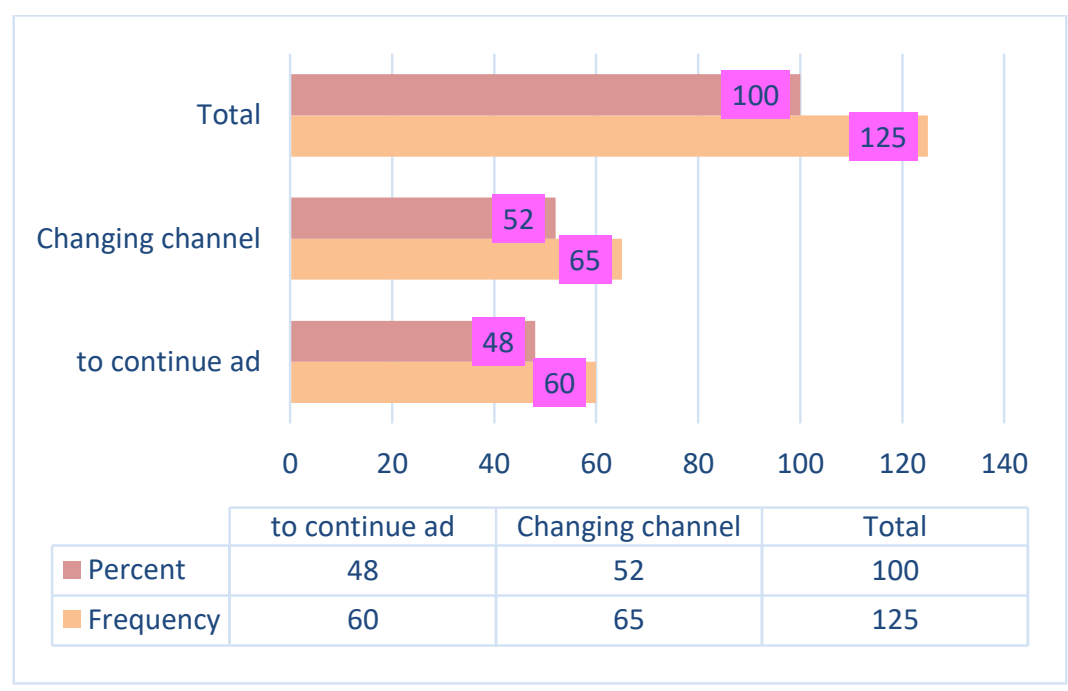

Figure-4: Children's reaction after watching advertisements.

Figure-4 displays $65(52 \%)$ respondents who change the channel when the advertisements start while lower part of the respondents 60 (48\% do not change the channel when the advertisements start.

\subsection{Type of advertisements in which children have interest}

\begin{tabular}{|l|c|c|}
\hline & Frequency & Percent \\
\hline FOOD & 13 & 10.4 \\
\hline TOYS & 72 & 57.6 \\
\hline STATIONARY & 21 & 16.8 \\
\hline OTHERS & 19 & 15.2 \\
\hline TOTAL & 125 & 100 \\
\hline
\end{tabular}

Table-3: Type of advertisements in which children have interest.

Table-3 shows that maximum of the $72(57.6 \%)$ respondents attracted to toys advertisements while second respondents $21(16.8 \%)$ attracted to stationary advertisements. $13(10.4 \%)$ respondents attracted to food advertisements and $19(15.2 \%)$ respondents attracted to others advertisements.

\subsection{Children's interest in watching advertisement of new products}

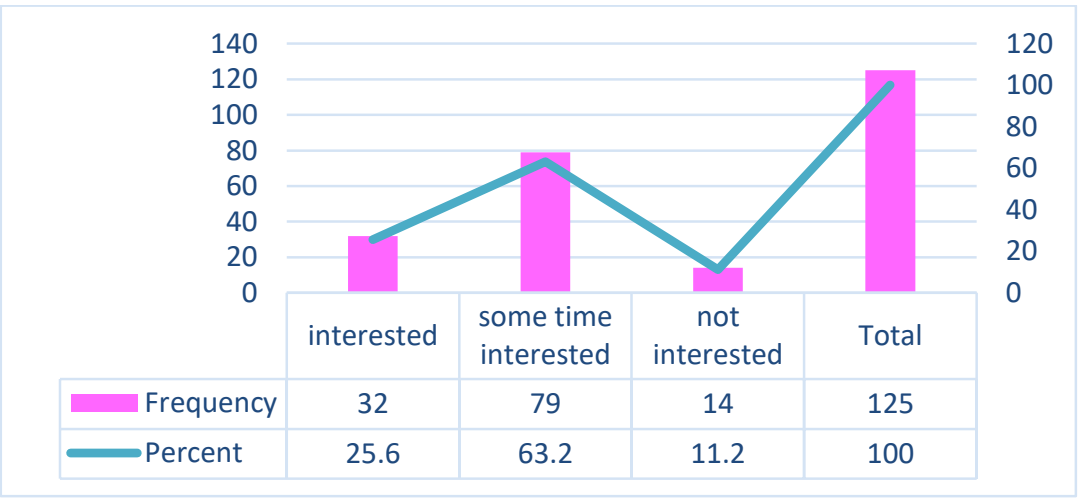

Figure-5: Children's interest in watching advertisement of new products.

Figure-5 represents most of the respondents 79 (63.2\%) sometime interested in watching television while second largest 32 (25.6\%) respondents interested in watching television and lower 14 (11.2\%) respondents do not interested in watching television. 


\subsection{Attraction of children towards the model shown in advertisements}

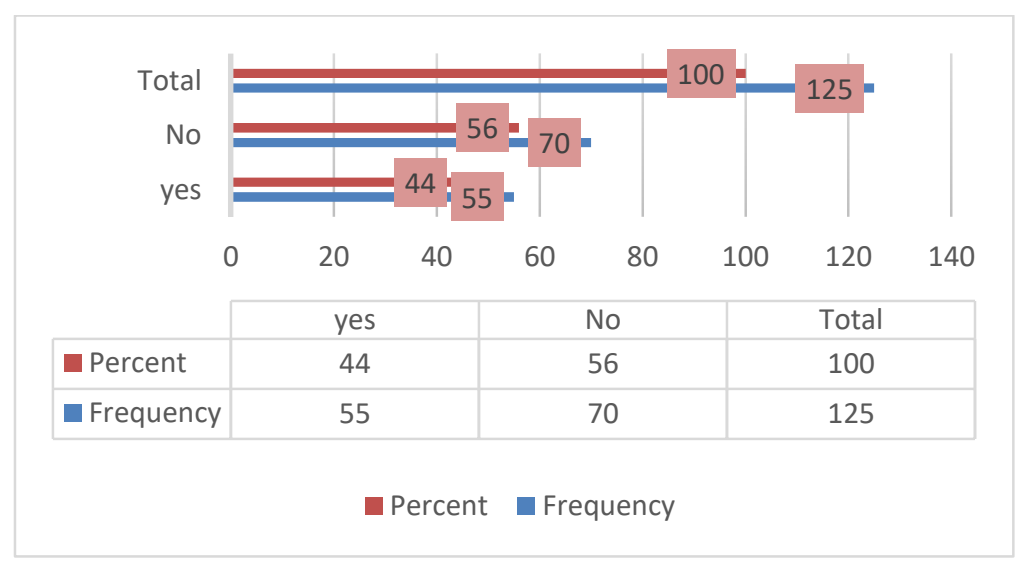

Figure-6: Attraction of children towards the model shown in advertisements

Figure-6 reveals $70(56.0 \%)$ respondents do not attracted to model when they are shown in the advertisement while lower part of the respondents $56(44.0 \%)$ attracted to model when they are shown in the advertisement.

\subsection{Children's practice to be like a model in personal life after watching ads}

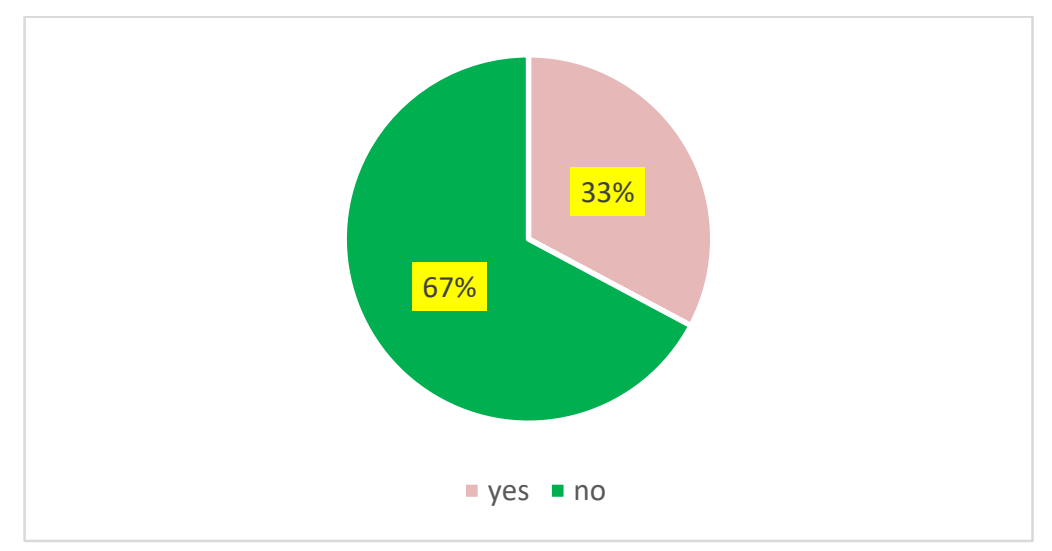

Figure-7: Children's practice to be like a model in personal life after watching ads.

Figure-7 shows $84(67.0 \%)$ respondents do not practice the model in their personal life while $16(33.0 \%)$ respondents practice the model in their personal life.

\section{9 change in children's behavior after watching advertisement}

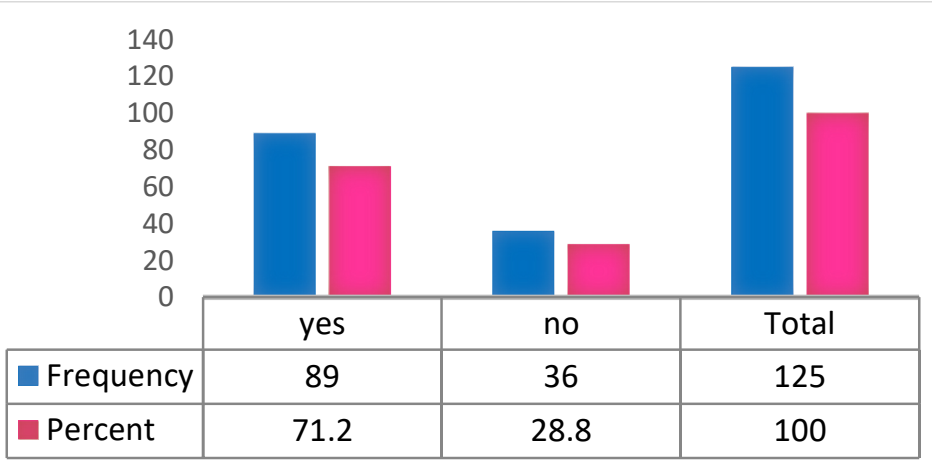

Figure-8: change in children's behavior after watching advertisement 
Figure-8 reveals that $89(71.2 \%)$ respondents notice that their child change for watching advertisement while $36(28.8 \%)$ respondents notice that their child do not changing for watching advertisement.

\subsection{Changes in children}

\begin{tabular}{|l|c|c|}
\hline & Frequency & Percent \\
\hline TRUST AD THAN YOU & 7 & 5.6 \\
\hline TRY TO GIVE EXAMPLE TO AD & 30 & 24 \\
\hline CHANGING BEHABIOUR & 63 & 50.4 \\
\hline CHANGING LANGUAGE & 25 & 20 \\
\hline TOTAL & 125 & 100 \\
\hline
\end{tabular}

Table-4: Changes in children.

Table-4 shows highest of the 63 (50.4\%) respondent's child change behavior while second largest of the $30(24.0 \%)$ respondent's child try to give example to ads. $25(20.0 \%)$ respondent's child changes language and lower part of the respondents $5.6 \%$ trust ads than their parents.

\subsection{Amount of views arises among the respondents after watching Ads}

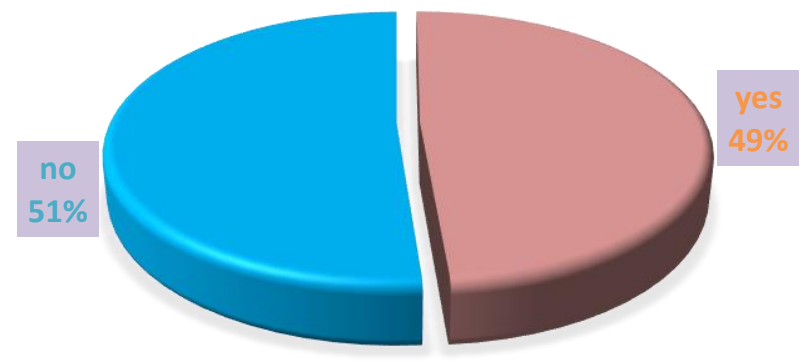

Figure-9: Amount of views arises among the respondents after watching Ads.

Figure-9 displays most of the $64(51.2 \%)$ respondents who reply that different views do not arise in their life and their family member due to watching advertisement while 61 (48.8\%) respondents replay that different views arise in their life and their family member due to watching advertisement.

\subsection{Complain against children regarding TV Ads}

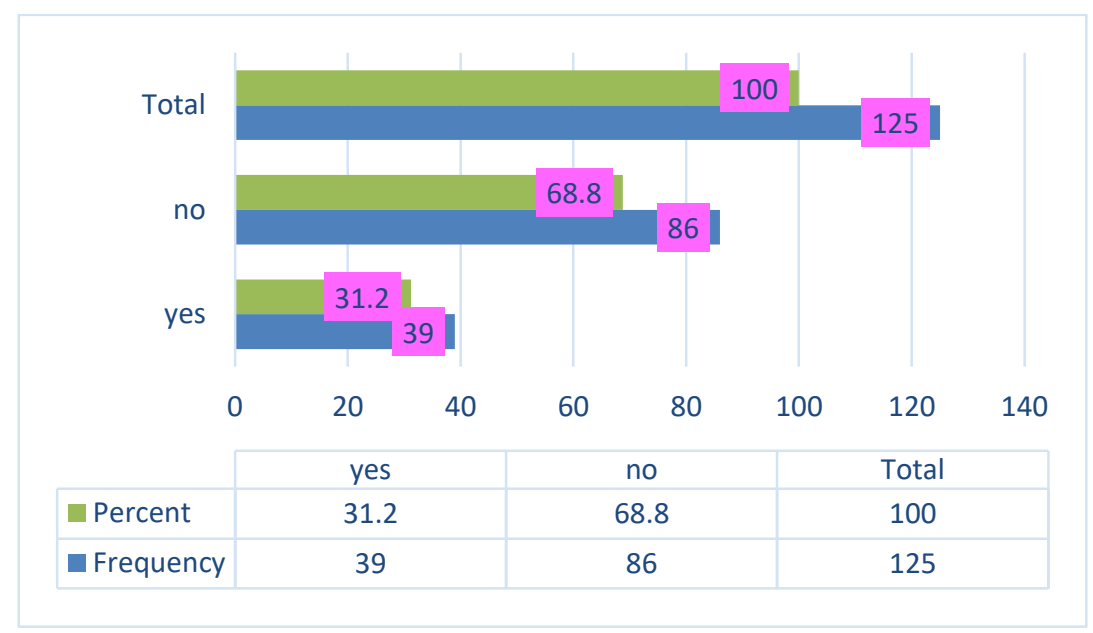

Figure-10: Complain against children regarding TV Ads. 
Figure-10 shows almost three fourth of respondents $86(68.8 \%)$ replay that anyone does not complain against them while lower part of the respondents 39 (31.2\%) replay that someone complains against them regarding that.

\subsection{Problems of children for watching Ads}

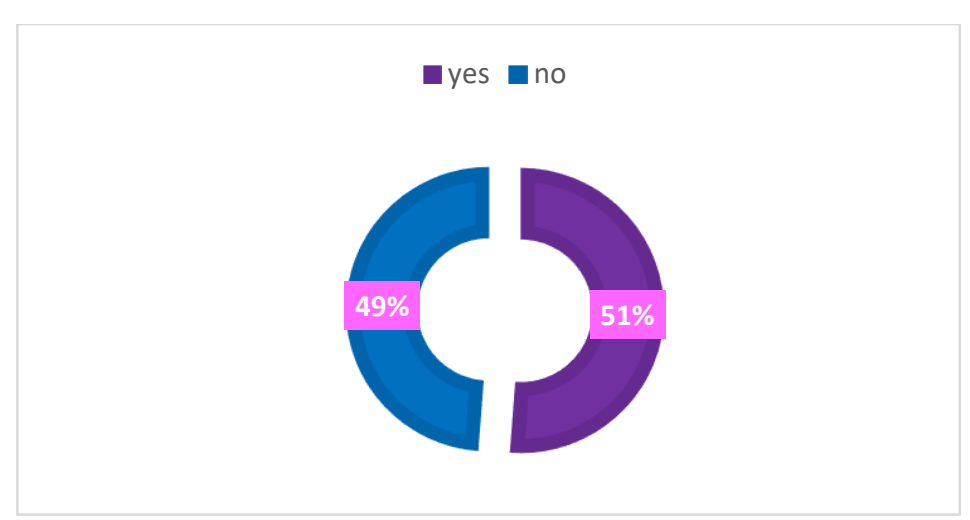

Figure-11: Problem of children for watching Ads.

Figure-11 presents more than half of the respondents $51 \%$ replay that problem arises regarding education while lower part of the respondents $49 \%$ replay that problem does not arise regarding education.

\subsection{Obligation from School regarding children's behavior}

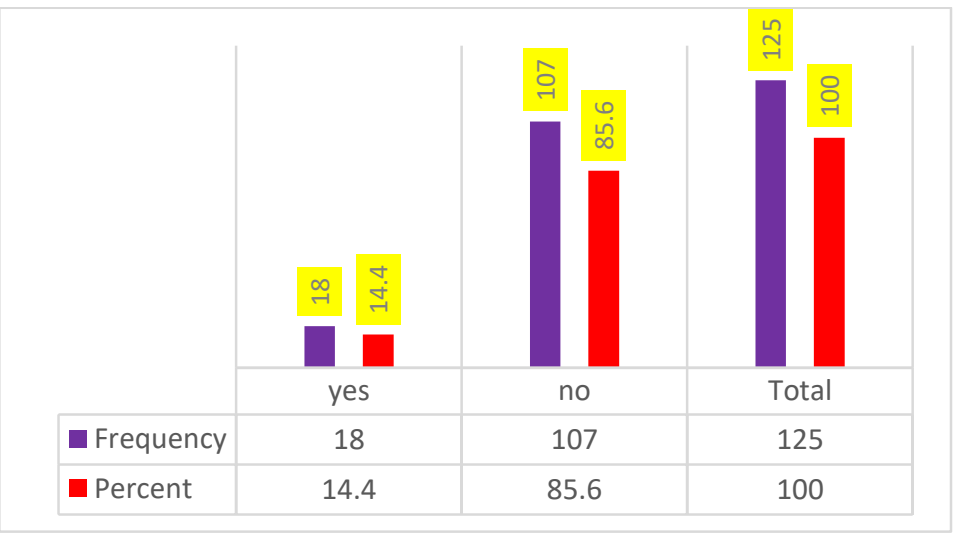

Figure-12: Obligation from School regarding children's behavior.

Figure-12 reveals majority of the $107(85.6 \%)$ respondents say that the obligation do not come from school regarding his or her behavior while $18(14.4 \%)$ respondents say the obligation come from school regarding his or her behavior.

\subsection{Children's priority to product while buying anything}

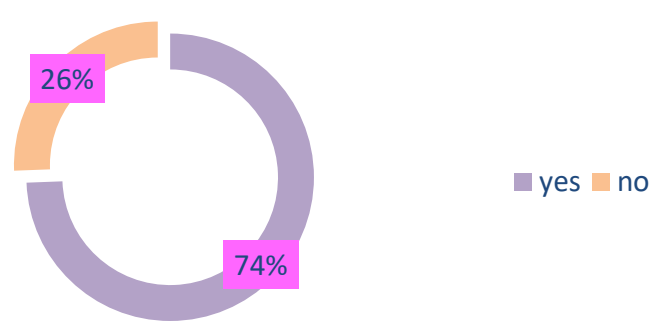

Figure-13: Children's priority to product while buying anything. 
Figure-13 shows $93(74.4 \%)$ respondents replay that their children give priority to buying product to watch the ads while $32(25.6 \%)$ respondents replay that their children do not give priority to buying product to watch the ads.

\subsection{Children's interest in advertisement}

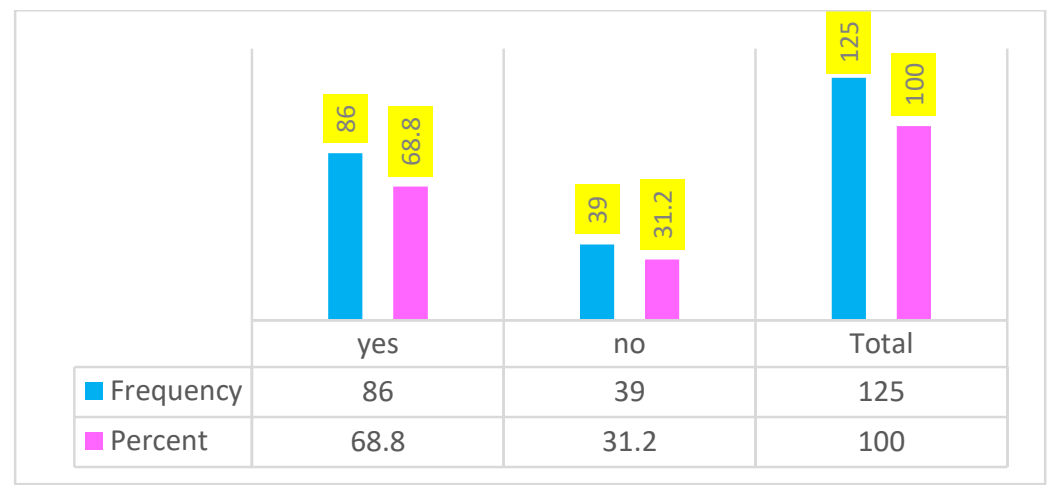

Figure-14: Children's interest in advertisement.

Figure-14 presents' 86 (68.8\%) respondents watch ads when it is shown while $39(31.2 \%)$ respondents do not watch ads when it is shown.

\subsection{Children's likings in advertisement}

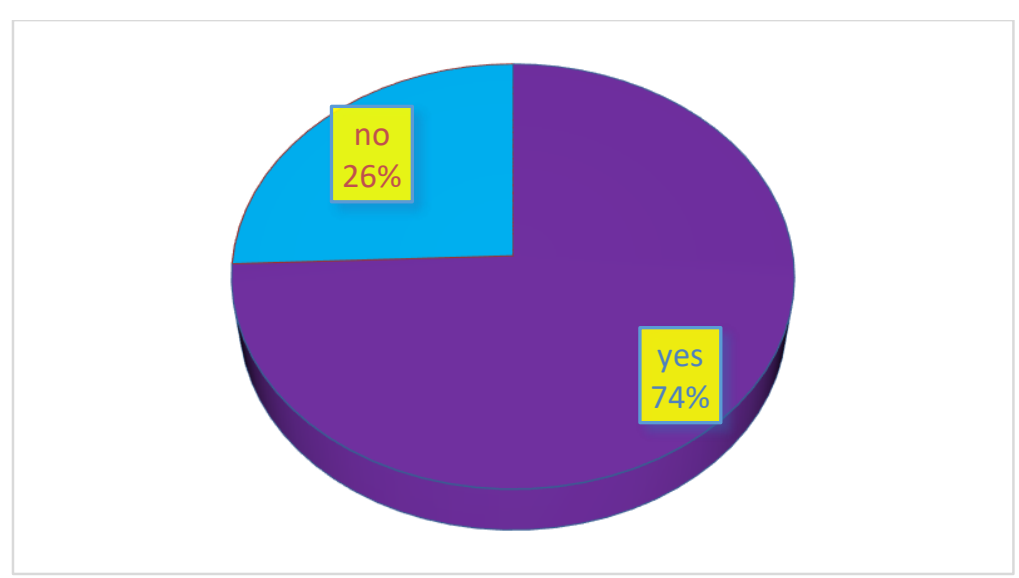

Figure-15: Children's likings in advertisement.

Figure-15 shows 93 (74.4\%) respondents wish to buy the product what is shown in advertisement while $32(25.6 \%)$ respondents do not wish to buy the product what is shown in advertisement.

\subsection{Children's deeds if they wish to buy a product}

\begin{tabular}{|l|c|c|}
\hline TO SAY PARENTS & 62 & 49.6 \\
\hline TO REQUEST & 36 & 28.8 \\
\hline TO ORDAR & 5 & 4 \\
\hline TRY TO BUY SELF & 22 & 17.6 \\
\hline TOTAL & 125 & 100 \\
\hline
\end{tabular}

Table-5: Children's deeds if they wish to buy a product.

Table-5 revels $62(49.6 \%)$ respondents to simply say their parents to buy the product while $36(28.8 \%)$ respondents to request to buy the product. $22(17.6 \%)$ respondents try to buy the self of the product and $5(4.0 \%)$ respondents to order their parents buy the product when they are watching the ads. 


\subsection{Children's reaction when it is delayed to buy}

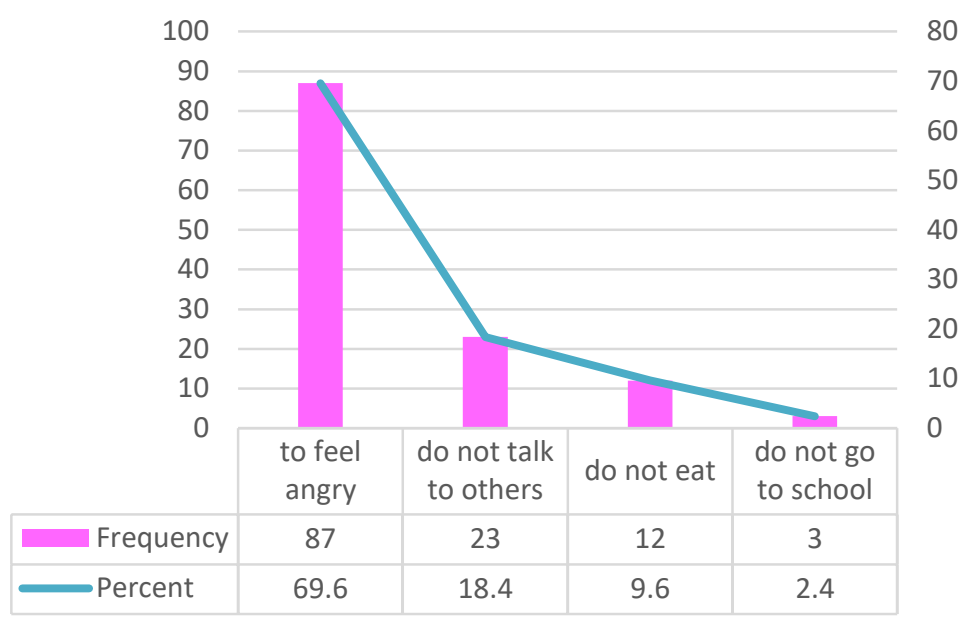

Figure-16: Children's reaction when it is delayed to buy.

Figure-16 shows $87(69.6 \%)$ respondents feel to angry, 23 (18.4\%) respondents do not talk to others, $12(9.6 \%)$ respondents do not eat and $3(2.4 \%)$ respondents do not go to school if their parents do not give to buy the product.

\subsection{Children's desire to act what is enacted in advertisement}

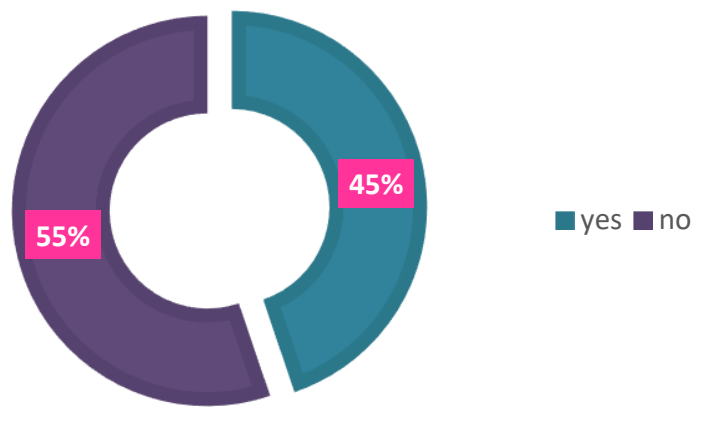

Figure-17: Children's desire to act what is enacted in advertisement.

Figure-17 displays majority of respondents 69 (55.2\%) do not desire to act what is enacted in advertisement while $56(44.8 \%)$ respondents desire to act what is enacted in advertisement.

\subsection{Children's range of practicing enacted in advertisement}

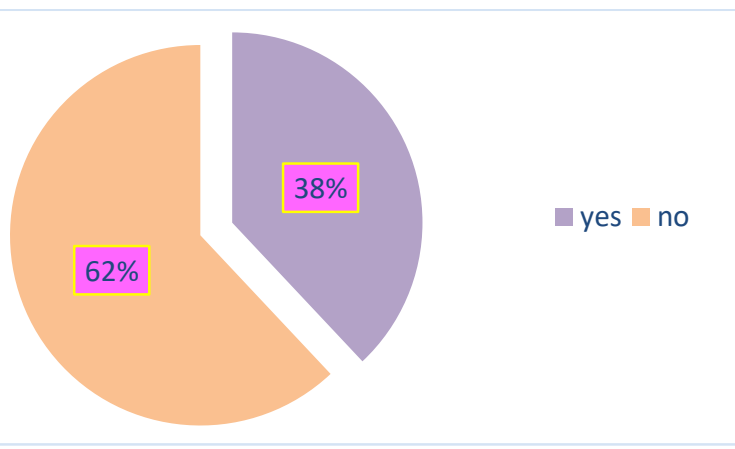

Figure-18: Children's range of practicing enacted in advertisement. 
Figure-18 shows 77 (61.6\%) respondents' replay that they do not practice occasionally that desire to act what is enacted in advertisement while $48(38.4 \%)$ respondents replay that they practice occasionally that desire to act what is enacted in advertisement.

\subsection{Parents' range of chide when children watch advertisement more}

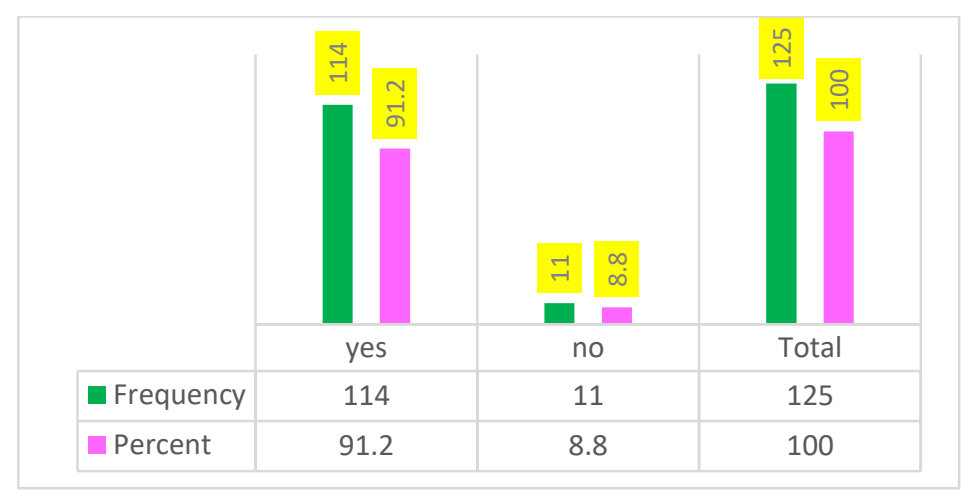

Figure-19: Parents' range of chide when children watch advertisement more.

Figure-19 shows maximum $114(91.2 \%)$ respondents replay that their parents chide if they are watching more ads while $11(8.8 \%)$ respondents replay that their parents do not chide if they are watching more ads.

\subsection{Children's deeds if their parents chide}

\begin{tabular}{|l|c|c|}
\hline & Frequency & Percent \\
\hline TO FEEL UPSET & 54 & 43.2 \\
\hline TO ANGRY & 3 & 2.4 \\
\hline TO FEEL PAIN & 8 & 6.4 \\
\hline DO NOT OBEY & 12 & 9.6 \\
\hline TO STOP AD & 48 & 38.4 \\
\hline TOTAL & 125 & 100 \\
\hline
\end{tabular}

Table-6: Children's deeds if their parents chide.

Table-6 shows that most of the $54(43.2 \%)$ respondents replay that they feel upset if their parents chide while second largest $48(38.4 \%)$ to stop ads and 12 (9.6\%) respondents replay that they do not obey if their parents chide. $8(6.4 \%)$ respondents replay that they feel pain if their parents bicker and $3(2.4 \%)$ respondent replay that they feel angry if their parents chide. So, the table revels that most of the respondents feel upset if their parents chide them.

\section{DISCUSSION}

In this study more than half of the respondents were from female respondents whereas more than two fifth of the respondents were from male respondents. The study shows that most of the respondents (82\%) watched television in holiday, one fourth of the respondents spend two to four hours to watch the television.

This study presents that almost three fifth of the respondents were attracted to toys and food advertisements in television. Gulraiz Ghaffar, Usma Noreen (2016) found the similar result that often three fifth of the respondents were attracted to toys and food advertisements. Galdolage B.S., Wijesundara C.B. (2016) found that maximum number of the respondents changed their behavior after watching the advertisements. This study shows the similar relation that highest number of the respondents were influenced by advertisements and they changed their behavior.

This study shows that almost three fourth of the respondents want to buy the products what they watched in advertisements at television. Sunita Kumar (2013), often showed the similar relation. The study reveals that three fourth of the respondents watched television medium, more than half of the respondents were attracted towards model shown in advertisement, one third of the respondents 
practiced what they see displayed in advertisements, more than two third of the respondents replied that did not complain against their children due to watch the advertisement, more than half of respondent replied that watching ads created problems for their children in education.

The study also finds that three fourth of the respondents gave priority to buy products on the basis of advertisements, more than half of the respondents wanted to act what they watch in television, maximum number of the responds $(91.2 \%)$ chided their children due to watch the advertisements, more than two fifth $(43.2 \%)$ of the respondents felt angry if their parents chided them.

\section{RECOMMENDATIONS}

1. In television, ads should be included considering the children and should be organized in such a way that those can work as learning equipment.

2. No vulgar scene should not include in television ads because they can change the psyche of the children.

3. Moreover, the harmful foods or products should not be shown in an attractive way because after watching those ads, children's mental behavior changes and they argue with parents for getting those products.

4. The parents should not always leave their children to pass their time by watching television ads and they should be aware of this matter.

5. The parents should encourage their children to watch informative ads.

\section{CONCLUSION}

Day by day TV advertisement is regularly and consistently changing and coming up with brand new ideas, improvements and innovations to show its products on TV for the viewers' especially for children to get influenced. In this study, we explored that TV advertisements have a lot of impact on children's behavior. TV advertisements mostly target children as we all know that children have some weak insights about the goods and products which are best for them and which are not best for them. This can help those parents who really need to know why change their children's behavior after viewing TV ads. And also this study will be beneficial for the society as well as the researcher of this field.

\section{ACKNOWLEDGEMENT}

We cannot express enough thanks to Khulna University authority and head of Mass Communication and journalism discipline for their continued support and encouragement; Prof. Dr. Mohammad Fayekuzzaman, honorable vice chancellor, KU; Prof. Dr. Mosummath Hosna Ara, head, Mass Communication and Journalism discipline, KU. We offer our sincere appreciation for the learning opportunity provided by them.

This project could not have been accomplished without the support of our colleagues and Students. Thank you for allowing us time away from you to research and write.

In this entire research, from study design to submission there was no external funder or financial sponsor. All the expense of this study was from researchers own funding.

Finally, to our caring, loving and supportive parents and family, who kept their faith and support in us till end. Our heartfelt thanks.

\section{REFERENCES}

Adler, R. P, Lesser, G. S, Merngff, L, Robertson, T, Rossiter, J, \& Ward, S. (1997) 'Research on the effects of television advertising to children. A review of the literature and recommendation for future research', US Government Printing office, Washington. DC. Available at: https://eric.ed.gov/?id=ED145499 (accessed 10 February 2019)

Andreyeva, T., Kelly, IR., \& Harris, JL. (2011). 'Exposure to food advertising on television: Associations with children's fast food and soft drink consumption and obesity’, Economics \& Human Biology, vol. 9, no. 3, Pp. 221-233

Andronikidis, A.I. \& Lambrianidou, M. (2010). 'Children's understanding of television advertising: A grounded theory approach', Psychology and Marketing, vol. 27, no. 4, pp. 299-322. 
Bandyopadhyay, S. K. (2001), "Is Television Advertising Good for Children? Areas of Concern and Policy Implications", International Journal of Advertising, Vol. 20, No.1. Available at: https://www.researchgate.net/publication/267221173_Is_Television_Advertising_Good_for_Children_Areas_of_Concern_and_Policy_Implications (accessed 12 February 2019)

Batounis-Ronner, C., Hunt, J. \& Mallalieu, L. (2007) `Sibling effects on preteen children's perceived influence in purchase decisions'. Young Consumers. Available at: https://www.emerald.com/insight/content/doi/10.1108/17473610710838590/full/html (accessed 15 February 2019)

Borzekowski, D. L. G., \& Robinson T. N. (2001) 'Pitching to preschoolers: The impact of television food commercial on sample of Head Start Children', Journal of the American Dietic Association, vol. 101, pp. 42-46.

Buijzen M and Valkenburg P (2003), "The Iffect of Television Advertising on Materialism, Parent-Child Conflict, and Unhappiness: A Review of Research", Journal of Applied Developmental Psychology, vol. 24, Issue-4, pp. 437-456.

Dale kunkel, (1992), 'Children's television advertisements in the multi-channel environment', journal of communication, vol. 42, no. 3, pp. 134-152

Evra, Judith van (1990): Television and Child Development. Hillsdale, NJ: Lawrence Erlbaum.

Gerbner, G. \& Gross, L.(1976), 'Living with television: The violence profile'. Journal of Communication, vol. 26, no. 2, pp. 172-199.

Hameed, M. A., Waqas, A., Aslam, M. N., Bilal, M., \& Umair, M. (2014). `Impact of TV Advertisement on Children Buying Behavior', International Journal of Humanities and Social Science, vol. 4, no. 2. Available at: http://www.ijhssnet.com/journals/Vol_4_No_2_Special_Issue_January_2014/25.pdf (accessed 10 February 2019)

Kunkel, D. (2001). 'Children and television advertising', Handbook of children and the media, pp. 375-394, Thousand Oaks, CA: Sage

Mittal, M., Daga, A., Chhabra, G., Lilani, J. (2010), "Parental Perception of the Impact of Television Advertisements on Children's Buying Behavior", The IUP Journal of Marketing Management, Vol. IX, No. 1 \& 2.

Pine, K. J. \& Nash, A. (2002), "Dear Santa, The effect s of television advertising on young children". International Journal of Behavioural Development, vol. 26, Pp. 529-539.

Roedder, D.L. (1981), ‘Age differences in children's responses to television advertising: an information processing approach', Journal of Consumer Research, vol. 8, no. 2, pp. 144-53.

Singh, S. and Kaur, J. (2011), "The Impact of Advertisements on Children's and Their Parents Buying Behavior: An Analytical study", The IUP Journal of Marketing Management. Available at: https://www.researchgate.net/publication/256022156_The_Impact_of_Advertisements_on_Children_and_Their_Parents'_Buying_Behavior_An_Analytical_Study (accessed 20 February 2019)

Stoneman Z and Brody G H (1982), "The Indirect Impact of Child-Oriented Advertisements on Mother Child Interactions", Journal of Applied Developmental Psychology, Vol. 2, No. 4, pp. 369-376. 